\title{
Killer immunoglobulin-like receptor genes and heterosexual HIV-1 transmission
}

\author{
Aimee Merino ${ }^{1 *}$, Rakhi Malhotra ${ }^{1}$, Matt Morton ${ }^{1}$, Joseph Mulenga ${ }^{2,3}$, Susan Allen ${ }^{2,3}$, Eric Hunter ${ }^{3}$, Jianming Tang ${ }^{1}$, \\ Richard Kaslow'
}

From $16^{\text {th }}$ International Symposium on HIV and Emerging Infectious Diseases

Marseille, France. 24-26 March 2010

\section{Background}

Killer immunoglobulin-like receptor (KIR) genes regulate natural killer cell function. KIR gene content has been reported to influence HIV-1 acquisition and progression, but consensus is lacking. We investigated the impact of KIR and KIR/HLA genes on heterosexual transmission in an African cohort.

\section{Methods}

Between 1995 and 2006, 566 HIV-1 serodiscordant couples in Zambia, were followed for counseling and serologic testing for a minimum of nine months. KIR genes and HLA alleles were detected by standard typing methods. We tested the association of KIR genes and KIR gene/HLA ligand combinations with HIV-1 transmission and with index partner viral load (VL). All analyses of VL by linear regression were adjusted for age, sex, and time from enrollment. Covariates in proportional hazards models of HIV-1 transmission included VL in all index partners and genital ulcers in all partners.

\section{Results}

In the index partners KIR2DS4*001, the only KIR2DS4 allele to encode a full length receptor, was associated with higher rates of HIV-1 transmission $(\mathrm{OR}=2.40$, $95 \% \mathrm{CI}=1.31-4.39, p=0.003)$ by logistic regression. Survival analysis for KIR2DS4*001 demonstrated accelerated transmission of HIV-1 ( $\mathrm{RH}=1.72, p=0.005)$. This allele in the seronegative partners was not associated with acquisition. The KIR2DS4*001 allele was also associated with a high VL $\left(0.17 \pm 0.08 \log _{10}, p<\right.$ 0.05). No association was observed with its ligand, HLA$\mathrm{Cw}^{* 04}$, or with the HLA-Cw*04/KIR2DS4*001

\footnotetext{
* Correspondence: amerino@uab.edu

${ }^{1} \cup A B$, Birmingham, USA
}

combination. Previously reported findings on other KIR genes could not be confirmed.

\section{Discussion}

We observed an association of KIR2DS4*001 carriage by a seropositive partner with an increased hazard of HIV1 transmission and with high VL. Whatever the significance of this KIR allele association in Zambian couples, it did not depend on epistatic interaction with HLA$\mathrm{Cw}^{*} 04$. The association will require confirmation in functional assays.

\section{Author details}

${ }^{1}$ UAB, Birmingham, USA. ${ }^{2}$ Rwanda-Zambia HIV Research Group, Lusaka, Zambia. ${ }^{3}$ Emory, Atlanta, USA.

Published: 11 May 2010

doi:10.1186/1742-4690-7-S1-P105

Cite this article as: Merino et al:: Killer immunoglobulin-like receptor genes and heterosexual HIV-1 transmission. Retrovirology 2010 7(Suppl 1): P105.

Submit your next manuscript to BioMed Central and take full advantage of:

- Convenient online submission

- Thorough peer review

- No space constraints or color figure charges

- Immediate publication on acceptance

- Inclusion in PubMed, CAS, Scopus and Google Scholar

- Research which is freely available for redistribution

Submit your manuscript at www.biomedcentral.com/submit
C Biomed Central 